DOI https://doi.org/10.30525/978-9934-26-046-9-14

\title{
АНАЛІЗ ЗАВДАНЬ І МЕТОДІВ ОЦІНКИ ТА ВИБОРУ АЛЬТЕРНАТИВ РІШЕНЬ
}

\author{
Троцько О. О.
}

доцент кафедри автоматизованих систем управління

Військовий інститут телекомунікаиій та інформатизаиії імені Героїв Крут

\section{Симоненко О. А.}

старший викладач кафедри автоматизованих систем управління Військовий інститут телекомунікацій та інформатизації імені Героїв Крут

\section{Лазута P. P.}

старший науковий співробітник Наукового иентру

Військовий інститут телекомунікацій та інформатизаиії

імені Героїв Крут

м. Київ, Україна

Вступ. Процес прийняття рішень складається 3 ряду стадій (етапів). На початковому етапі необхідно виявити проблему, проблемну ситуацію або певну предметну область, в яких потрібне прийняття рішень.

Термін «рішення» має багато смислових значень. Це можуть бути дії щодо вирішення проблем, що призводять до якогось результату, наслідки яких необхідно оцінити. Під рішенням розуміють також деякі об'єкти, системи, що вимагають оцінювання. Рішення це також різні варіанти, альтернативи, можливості щодо дій і об'єктів.

На наступному етапі необхідно змістовно описати предметну область, виявити цілі прийняття рішень і обмеження.

Далі потрібно здійснити збір та аналіз детальної інформації про предметну область. У ряді випадків необхідно побудувати модель, визначити область альтернатив (варіантів) рішень, виконати генерацію рішень, сформулювати завдання прийняття рішень. 
На наступному етапі здійснюється прийняття рішень на основі обраних (розроблених) методів. Виконується оцінка варіантів рішення, їх порівняння, класифікація, ранжування, вибір найкращого.

I, нарешті, заключна фаза пов'язана з реалізацією рішення і оцінки його наслідків.

Виклад основного матеріалу дослідження. Залежно від повноти і вихідних даних завдання вибору рішень можуть бути добре структурованими, слабо структурованими i неструктурованими [1-4]. Для добре структурованих задач дані формулюються в кількісному вигляді, для слабо структурованих задач вони містять кількісні опису з домінуванням якісних і невизначених факторів, для неструктурованих завдань дані представляються у вигляді якісного опису вихідних факторів і взаємозалежностей між ними.

Вибір рішень може здійснюватися в умовах визначеності, ризику або невизначеності $[3,4]$. В умовах визначеності відомі вихідні дані і наслідки кожної альтернативи рішень.

Умови ризику мають місце, якщо відомі ймовірності альтернатив рішень або відомий закон розподілу їх ймовірностей. Тоді задача зводиться до вибору статистичних рішень. У свою чергу, умови ризику можна визначити як умови стохастичною невизначеності, породжені випадковими факторами, які при їх масовій появі мають властивість статистичної стійкості і описуються будь-яким законом розподілу ймовірності.

Умови невизначеності, при яких закон розподілу ймовірностей для невизначених факторів невідомий, визначаються як умови статистичної невизначеності. Умови статистичної невизначеності, в свою чергу, діляться на два види: по-перше, з відомими параметрами розподілу (математичне очікування, дисперсія та інші характеристики випадкової величини); по-друге, з невідомими параметрами розподілу.

До основних завдань оцінки і вибору альтернатив рішень можна віднести такі: оцінка альтернатив рішень; порівняльна оцінка і ранжування безлічі альтернатив рішень; визначення стратегій оцінювання альтернатив рішень; визначення значень часткових показників рішень по заданих значенням узагальненого показника; пошук значень часткових показників, що забезпечують необхідні значення узагальненого показника; пошук найкращих рішень (значень часткових показників), що забезпечують необхідні значення узагальненого показника. 
Можна виділити одно- і багатокритеріальні методи оцінки і вибору альтернатив рішень.

В однокритеріальному випадку вважаються відомими: безліч альтернатив рішень (об’єктів, варіантів дій); оцінка альтернатив за обраним критерієм (показником) та правило вибору найкращого варіанту.

Іншим випадком завдання вибору є ранжування варіантів рішень відповідно до безлічі оцінок альтернатив. Найбільш значним для практичного використання $\epsilon$ випадок оцінки і вибору альтернатив за багатьма критеріями.

У багатокритеріальному випадку кожному варіанту можна поставити в відповідність вектор, що представляє оцінки варіанту за критеріями (показниками).

Далі підходи до порівняння і вибору варіантів рішень можуть бути розділені на дві великі групи: зведення і не зведення багатьох критеріїв до одного.

Методи, засновані на незведенні багатокритеріальних задач оцінки і вибору варіантів рішень до одного критерію, ставлять своїм завданням порівняння варіантів на основі векторів оцінки за всіма критеріями. Серед важливих факторів, що враховуються при вирішенні цього завдання, можна вказати вагу (важливість) критеріїв. Часто ці методи використовуються в іншій постановці: пошук оптимальних рішень на безлічі параметрів, що визначають умови прийняття рішень.

Серед методів цієї групи можна виділити: метод домінування, метод на основі глобальних критеріїв, лексикографічне упорядкування, методи математичного програмування, методи порогів, методи теорії мультимножин [1-6] та інші.

Застосування цих методів обумовлено, як правило, незалежністю критеріїв, їх повною визначеністю.

У разі використання методів, заснованих на зведенні багатокритеріальних завдань оцінки і вибору варіантів рішень до одного критерію, завдання вибору вирішується на основі побудови інтегрального (узагальненого) критерію.

Для цього використовуються різноманітні способи агрегування, «згортки» показників, тобто побудови різних узагальнюючих показників, перш за все, адитивних і мультиплікативних.

Адитивний узагальнюючий критерій (показник) виходить як зважена сума оцінок за частковими критеріями (показниками). 
Однак наведені методи не завжди адекватно відображають особливості завдань оцінки і вибору, зокрема, взаємозалежність, суперечливості окремих показників.

Підхід, заснований на згортці багатьох критеріїв в один, використовується у багатьох методах теорії прийняття рішень, серед яких можна виділити наступні: методи, засновані на теорії цінності, корисності, методи аналізу ієрархій, методи нелінійної згортки, методи теорії нечітких множин та інші.

Висновки. Підхід до багатокритеріальної оцінювання складних об'єктів, заснований на зведенні багатьох критеріїв до одного, привабливий тим, що він знижує трудомісткість таких процедур теорії прийняття рішень, як порівняння, ранжування, класифікація і вибір варіантів (альтернатив).

Аналіз існуючих методів дозволяє зробити висновок про те, що вони не в повній мірі відображають особливості предметної області, які полягають в невизначеності, розвиненої системи сильно взаємодіючих різноякісних показників, складності оцінюваних об'єктів.

Загальним обмеженням використання розглянутих методів багатокритеріального оцінювання альтернатив $\epsilon$ складність формування багаторівневої структури оцінювання, а також вибору і налаштування операцій згортки показників.

\section{Література:}

1. Катулев А.Н., Северцев Н.А. Математические методы в системах поддержки выбора решений: учеб. пособие. Москва. Высшая школа. 2005. $311 \mathrm{c}$.

2. Ларичев О.И., Петровский А.Б. Системы поддержки выбора решений: современное состояние и перспективы развития. Итоги науки и техники. Москва. Высшая школа. т. 21. 1987. 323 с.

3. Ларичев О.И., Мошкевич Е.М. Качественные методы принятия решений. Москва. Наука, 1996. 401с

4. Макаров И.М., Виноградская Т.М., Рубчинский А.А., Соколов В.Б. Теория выбора и принятия решений. Москва. Наука, 1982. 330 с.

5. Dudnyk V., Sinenko Yu., Matsyk M., Demchenko Ye., Zhyvotovskyi R., Repilo Iu., Zabolotnyi O., Simonenko A., Pozdniakov P., Shyshatskyi A (2020). Development of a method for training artificial neural networks for intelligent decision support systems. Eastern- 
European Journal of Enterprise Technologies. 3, 2 (105), 37-47. DOI: https://doi.org/10.15587/1729-4061.2020.203301.

6. Pievtsov H., Turinskyi O., Zhyvotovskyi R., Sova O., Zvieriev O., Lanetskii B., and Shyshatskyi A. (2020). Development of an advanced method of finding solutions for neuro-fuzzy expert systems of analysis of the radioelectronic situation. EUREKA: Physics and Engineering, (4), 78-89. https://doi.org/10.21303/2461-4262.2020.001353

DOI https://doi.org/10.30525/978-9934-26-046-9-15

\title{
ЗАСТОСУВАННЯ ДЗЗ/ГІС-ТЕХНОЛОГІЙ ДЛЯ МОНІТОРИНГУ МІСЦЬ ЗАХОРОНЕННЯ ВІДХОДІВ
}

\author{
Шевчук О. В. \\ аспірант \\ Інститут телекомунікацій і глобального інформаційного простору \\ Національної академії наук Украӥни \\ м. Київ, Украӥна \\ Азімов О. T. \\ доктор геологічних наук, старший науковий співробітник, \\ провідний науковий співробітник \\ Науковий центр аерокосмічних досліджень Землі \\ Інституту геологічних наук Національної академії наук України \\ м. Київ, Україна \\ У наш час у переважній більшості країн світу, зокрема, й в Україні, \\ проблема забруднення навколишнього природного середовища різно- \\ манітними відходами стоїть дуже гостро, а отже $є$ актуальною. \\ В останні роки спостерігається значне зростання обсягів накопичення \\ побутових відходів різних типів (наприклад, твердих) на сміттєзвали- \\ щах та полігонах. \\ Полігони захоронення та сміттєзвалища твердих побутових від- \\ ходів (ТПВ) належать до екологічно небезпечних об'єктів. Їх експлуа- \\ тація призводить до забруднення практично всіх компонентів навко- \\ лишнього середовища - грунтів, поверхневих і підземних вод, атмо- \\ сферного повітря, рослинності тощо.
}

